\title{
Effect of Technology on Human Life Style, The World of Education, and The Development of Human Psychology
}

\author{
Harbeng Masni \\ University of Batanghari \\ Jambi, Indonesia
}

\begin{abstract}
Technological advances that are globalized have been affected in all aspects of life in economic, political, cultural, artistic and even education. Technological advances are something we cannot avoid in this life because technological advances will go according to the progress of science. One of the effects of technological development is the changing lifestyle. The development of technology is often closely related to the development of our lifestyles. Efficiency, practicality, and austerity can be achieved, but of course, everything does not always have a positive impact, there is also a negative impact or have negative sides. Technological developments also affect the world of education. With education, technology becomes easier. No need to meet face to face, meet the class of students have received an education. In developed countries already implement e-learning system; distance and space have not become a problem in an e-learning system. The required cost is also not expensive. Focusing on the broadest is view of learning behind the traditional learning paradigm. Most everyone is already using technology without exception. Indirectly the state of human psychology was changed or affected. Because the average man every day always do his job with the help of technology. In fact, there are often humans who more often interact with technology than interacting with other humans.
\end{abstract}

Keywords-Human life style, technology

\section{INTRODUCTION}

Technological advances that are globalized have been affected in all aspects of life in economic, political, cultural, artistic and even education. Technological advances are something we cannot avoid in this life because technological advances will go according to the progress of science. Every innovation is created to provide positive benefits for human life. Provide many conveniences, as well as a new way of doing human activities. Especially in the field of information technology has enjoyed many benefits brought by the innovations that have been generated in the last decade. However, although it was originally created to produce positive benefits, it is also possible to use for negatives [1], [2].

Along with the development of the era is accompanied by rapid technological developments, humans are now getting easier in doing their work. Technology is basically the whole means to provide the goods necessary for the survival and convenience of human life. Broadly speaking the technology was created to help people complete their work in everyday life in a precise, practical and brief. With the technology brought many changes in human life. The change can lead to the good or bad direction it depends on how the individual responds.

As time passes many innovations will produce new technology. The actual technology is used as a tool for human work. Today it seems to have "shackled" in the behavior of human life. Precisely technology is now leading human life. Humans seem to be used by technology. Indeed, the technology has a positive impact on humans. However, undoubtedly the negative impact of the development of technology is also felt by humans.

In ancient times before the development of human technology do the work manually so that requires a lot of energy is depleted. It is changing along with the development of technology, now humans eased his job, with a machine that is one of the energies that can complete the work on time and quickly. Basically, technology is created to help or alleviate the work of humans so that the work can run optimally effective and efficient.

Technological developments occur in various fields from transports, health, education, information, communication, and others. Technological developments cannot be avoided by anyone. Human also feels the change. To survive humans must be able to keep up with the changing times and technological advances. The development that occurs in technology causes various changes for humans in the activity, the lifestyle of humans also changes. Indonesian people tend to follow the lifestyle of Western society. It is a negative impact of technological developments. In addition, the world of technology education also brought considerable change. With technology, all things can be known quickly and transparently. Indirect technological changes in human psychology are also changing. Humans will continue to rely on technology. It would be better if the nature of dependence or rely on it slightly reduced. Now is the time for people to find innovation to produce new technology. Not only use but also create. 


\section{METHOD}

The research uses the secondary data and literature to explain the effect of technology on human life style. Secondary data and literature come from the newspaper, and data from the goverment agencies.

\section{RESULT AND DISCUSSION}

\section{A. Technology on Lifestyle}

One of the effects of technological development is the changing lifestyle. The development of technology is often closely related to the development of our lifestyles. Efficiency, practicality, and austerity can be achieved, but of course, everything does not always have a positive impact, there is also a negative impact or have negative sides. There are 3 (three) basic classifications of technological advances: neutral technological progress occurs when higher levels of output are achieved with the same quantity and combination of input factors, labor-saving technological advances saving technological progress) technological advances that have occurred since the late nineteenth century are marked by the rapid rise of labor-saving technologies in producing things and the advancement of capital saving technological progress.

If quoting from the opinion of Alvin Toffler is currently human is facing the third wave or third wave. First wave or the first wave of agrarian society (agriculture) took place in the year 1650-1750. At first wave or the first wave are known as planting period, in this wave all human activity done manually. Humans still use energy and muscle to freeze work, such as hoeing, hunting, planting is done manually and much power. Second wave or second wave of industrial society began in the 18th century named as a period of industrialization in which energy and muscle began to be replaced by machines. Industries began to replace human power with engine power. Production using machinery or mass production causes the country's economy to change. Third wave or third wave, this undulating machine is not fully replaceable, the machine is coupled with knowledge. This period is called the information age.

In the information, age emerged de-massification, decentralization, and consumerism. Demassification is a massive use of technology into individual users. Demassification can also be interpreted as an era marked by the more active user/communicant/audiences/consumers in using technology. But with the ever-evolving theory of human civilization with fierce competition and globalization, the fourth generation of human beings is called the knowledge-based economy or there is a call to creativity-oriented [3].

One of the most familiar technological developments is the internet. The Internet is one of the infinite sources of information that can be accessed by anyone and anywhere. Many people are starting to access the internet to find things they do not know yet. Especially for young people today is the Internet is one of the staple foods that is eaten every day. They use the internet as a medium of entertainment (social media, youtube, and others), educational media (science), and others.
If the internet is used wisely and properly then technology will bring positive value to the user.

There are still various parties who use the internet as a means of crime. Happened crime in the virtual world on average reached 14 crime cases every second in the international market, following the development of information technology in the present [4]. In addition to the internet, technology is quite familiar i.e. mobile phone or mobile phone. Today is probably only a small portion of young people who do not have mobile phones. If mobile phones today have become a necessity for the community. In addition, they assume that with mobile phones can all be fulfilled.

People's lifestyles began to change along with the development of technology. Society today does not want to be complicated by things that are less important. They prefer something instant, practical and quick example when they want to travel when the distance is not how much but they use a motorcycle or even a car but still can be reached by foot. In addition, to stay in touch they prefer via a mobile phone rather than meet directly, there is a positive value but if it is often done when it becomes negative. Moreover, the nature of consumerism that began to grow in society, it is a bad influence for the community. If they want to have a new technology (mobile phones, laptops, gadgets, and others) but they have no money, facilities. And even desperately they can commit theft, cheat, or even commit suicide. All that back to the family. It is the family who has a big enough role to manage the child's personality. But technology also has a positive impact on lifestyle

\section{B. Technology to the Education World}

Globalization of the world has triggered a shift in various aspects of the world, education including one of them. And education in the future will be more flexible. The development of technology, there are 5 (five) shifts in the learning process that is (1) from training to appearance, (2) from classroom to anywhere and anytime, (3) from paper to "online" or channel, (4) physical facilities to network facilities; and (5) from time to time cycle to real time [5].

Technological developments also affect the world of education. With education, technology becomes easier. No need to meet face to face, meet the class of students have received an education. In developed countries already implement e-learning system; distance and space have not become a problem in an e-learning system. The required cost is also not expensive. E-Learning is the use of internet technology in the delivery of learning in a wide range based on 3 criteria that are (1) e-learning is a network with the ability to update, store, distribute and share teaching materials or information, (2) delivery up to last user via computer using standard internet technology, (3) focusing on the broadest view of learning behind the traditional learning paradigm.

Currently e-learning has evolved in various ICT-based learning models such as: CBT (Computer Based Training), CBI (Computer Based Instruction), Distance Learning, Distance Education, CLE (Cybernetic Learning Environment), Desktop Videoconferencing, ILS (Integrated Learning 
System), LCC (Learner-Centered Classroom), Teleconferencing, WBT (Web-Based Training), and so forth [5].

The role of Information Technology in the education world according to PUSTEKKOM covers the utilization of information technology as follows: 1) skill and competence, 2) education infrastructure, 3) source of teaching materials, aids and educational facilities, and 4) education management. With the technology of educators can create an interesting learning process, easy to understand, and interactive. Student achievement can also increase. The benefits of technology to education are numerous and helpful in the education process. Learners can better understand the knowledge, is one of the supporting tools, can seek their own information without the teacher; can be used in improving the quality of education and others. So here the teacher is not the only source of knowledge because knowledge exists in various sources. With the many benefits provided the profits also gained a lot. Learners can easily access all information with the help of technology, so learners get the information and can be used as insight. In addition, with the technological power of educators can also easily carry out their duties. So that will create an advanced society.

The Internet has a lot of knowledge. With the development of technology (internet) is expected the learners can more easily find the source of learning, reference. The internet can be accessed by anyone and anywhere. Do not let the internet make children become lazy to learn because of the wrong use. We also still have to be vigilant because with the presence internet means there is also a danger. Dependence on the Internet must also be minimized by various ways in checking the truth and legality of the information obtained such as the various regions of the experts, the literature of scientific books that if possible the best sellers, journals, newspapers, magazines and the like.

\section{Technology to the Development of Human Psychology}

Nowadays technology is becoming a popular thing, discussed here. Most everyone is already using technology without exception. Indirectly the state of human psychology was changed or affected. Because the average man every day always do his job with the help of technology. In fact, there are often humans who more often interact with technology than interacting with other humans.

This is where the nature of individualism arises, humans are less able to socialize well, this situation is very disturbing his survival. Supposedly with the technology, we can be a better human not to because our technology shunned, avoided or even ostracized by friends, or the public. Back again to the main function of technology is to facilitate human work to be more effective and efficient.

Technological developments also provide positive impacts or benefits for human psychology, among others, individuals feel happy because it can obtain information easily (search engines in the browse, articles on the website), individuals will be more confident because it can appreciate his feelings through posts or posts (network social, or blog), individuals will be more open to change because of the changing flow of information from the internet, individuals will be happy to be able to innovate with their inventions (unique mobile phones, laptop modifications, etc.), individuals will be more motivated to create something more new, the individual will be more creative with the creatures that can help human performance, and the individual will be more active and have a wide network, because with today's technology allows one to interact with others both domestically and abroad [3].

Technology brings a negative impact on the psychological in humans among others (1) depedence, computer media has an attractive quality that can respond to any stimulus provided by the user. So, the user seems to find his new world. This dependence can be minimized with the supervision of parents, and reproduce activities outside the home, playing with friends, and self-busy so that activities in front of the computer is reduced; (2) antisocial behavior, dapak that arise one of them is a state where the user is no longer concerned with the social environment users prefer the technology they have. Users will rarely interact with the surrounding environment so that their interpersonal and emotional abilities do not develop optimally. If this condition continues to be left then the user will be a person who is very individualism and no interaction. Antisocial Behavior can still be overcome with self-awareness of the bad impact that will occur, reproduce activities outside the home with friends, family, traveling, hang-out, and others.

Utilization of information technology and ethics in utilizing information technology has been regulated by Law no. The Information Technology is a technique for collecting, preparing, storing, processing, announcing, analyzing, and/or disseminating information [6]. Information technology cannot be separated from electronic systems as regulated in Law No. 11 The year 2008 on Information and Electronic Transactions. Thus, information technology provides opportunities and opportunities to be utilized in bridging and support the development of human lifestyle and human development as a whole in accordance with the needs, which must have been filtered from various angles of usefulness.

Technology is an indispensable thing in life. But do not let technology that man. Dependence on technology will surely arise if everything is done always using technology. Humans should try not to become victims of technological developments. Humans must strive to improve their skills or expertise in order to participate in producing new technologies. The world of education, students can easily access all the information needed, this is where the emergence of plagiarism among students is a very harmful action. The students prefer to use the internet which is one of the technologies compared to reading a book whose contents are clearly more accurate. Perhaps this incident is influenced by the price of the book is relatively more expensive than accessing the internet, if any library as a means to borrow books may be a library that has poor quality and inadequate. So, the students take a more effective and efficient action. That is the consequence of the development of technology to education. Besides the existence of technology to education participate in the development of education. Education is now very modern, everyone can get good information in the form of scientific knowledge, news, and others quickly and transparently without having to get it through teachers and 
schools. It all depends on how the person has the initiative to advance himself because the sciences are now scattered everywhere.

Technology is very influential in the changes. Everyone always uses technology to help his work. Indeed, the technology is used to help humans, but do not be dependent on technology. The lifestyle of Indonesian society today refers to or imitates the Western style. The true lifestyle differs greatly from the Indonesian lifestyle. Indonesian society seems to have forgotten the true culture of Indonesia. Little by little Indonesian culture will be lost in time. The positive impact of Indonesian society today has largely understood the importance of knowledge about technology. Technology does bring negative and positive impact. Therefore, humans should be wise in using technology as it should, which is not just consumptive but also the creator. The technology cause human beings to be selfish, high individualize, and low social sense. If it happens, man has been harmed and utilized by technology.

As a young man who should continue the struggle of this country. We must be selective from the technology. Do not all technology be used alone, it's just like we are selfish. Do not be a young child who is a victim of technology but be a young boy who creates technology. Do not be a society that is not ready with technological developments, which should be done to improve the expertise that is favored seriously do not have any coercion from any side. But most young people today are very dependent on technology. Compare the first time the technology has not developed to relate to family, with friends we have to write a letter and to send it just takes a relatively long time. Now everything can run quickly we can through the phone or mobile phone that we have. The difference is very far away.

\section{CONCLUSION}

Technology is an indispensable thing in life. But do not let technology that man. Dependence on technology will surely arise if everything is done always using technology. Humans should try not to become victims of technological developments. Humans must strive to improve their skills or expertise in order to participate in producing new technologies. The world of education, students can easily access all the information needed, this is where the emergence of plagiarism among students is a very harmful action. The students prefer to use the internet which is one of the technologies compared to reading a book whose contents are clearly more accurate. Perhaps this incident is influenced by the price of the book is relatively more expensive than accessing the internet, if any library as a means to borrow books may be a library that has poor quality and inadequate. So, the students take a more effective and efficient action. That is the consequence of the development of technology to education. Besides the existence of technology to education participate in the development of education. Education is now very modern, everyone can get good information in the form of scientific knowledge, news, and others quickly and transparently without having to get it through teachers and schools. It all depends on how the person has the initiative to advance himself because the sciences are now scattered everywhere.

Technology is very influential in the changes. Everyone always uses technology to help his work. Indeed, the technology is used to help humans, but do not be dependent on technology. The lifestyle of Indonesian society today refers to or imitates the Western style. The true lifestyle differs greatly from the Indonesian lifestyle. Indonesian society seems to have forgotten the true culture of Indonesia. Little by little Indonesian culture will be lost in time. The positive impact of Indonesian society today has largely understood the importance of knowledge about technology. Technology does bring negative and positive impact. Therefore, humans should be wise in using technology as it should, which is not just consumptive but also the creator. Do not let the technology because human beings to be selfish, high individualize, and low social sense. If it happens man has been harmed and utilized by technology.

As a young man who should continue the struggle of this country. We must be selective from the technology. Do not all technology be used alone, it's just like we are selfish. Do not be a young child who is a victim of technology but be a young boy who creates technology. Do not be a society that is not ready with technological developments, which should be done to improve the expertise that is favored seriously do not have any coercion from any side. But most young people today are very dependent on technology. Compare the first time the technology has not developed to relate to family, with friends we have to write a letter and to send it just takes a relatively long time. Now everything can run quickly we can through the phone or mobile phone that we have. The difference is very far away [7], [8], [9].

\section{REFERENCES}

[1] C.M. Gairola, Information and Communications Technology for Development. New Delhi: Elsevier, 2004.

[2] Hariningsih, Teknologi Informasi, Penerbit Graha Ilmu, 2005.

[3] Kompasiana, Dampak Perkembangan Teknologi Informasi diunduh dari http://m.kompasiana.com/488600/1/dampak-perkembanganteknologi-informasi), pada 29 Oktober 2016

[4] Republika, Kejahatan di Dunia Maya diunduh dari (http://m.republika.co.id/berita/trendtek/internet/12/03/16/m0tjf2setiap-detik-terjadi-14-kejahatan-di-dunia-maya), pada 29 Oktober 2016

[5] Kompasiana, Peranan TIK dalam Dunia Pendidikan diunduh dari (http://m.kompasiana.com/3/tik-peranannya-dalam-dunia-pendidikandan-peranan-guru-dalam-pembelajaran-tik), pada 29 Oktober 2016.

[6] Law No. 11 of 2008 on Information and Electronic Transactions (ITE) in Article 1 paragraph (3) Year 2008.

[7] Munir, Pembelajaran Jarak Jauh Berbasis Teknologi Informasi dan Komunikasi. Bandung, Penerbit: Alfabeta, 2009

[8] Munir, Dampak Teknologi Informasi dan Komunikasi Dalam Pendidikan. Bandung, Penerbit: Universitas Pendidikan Indonesia, 2008

[9] C.R. Semiawan, Mencari Strategi Pengembangan Pendidikan Nasional Menjelang Abad XXI, Jakarta: Grasindo, 1991 